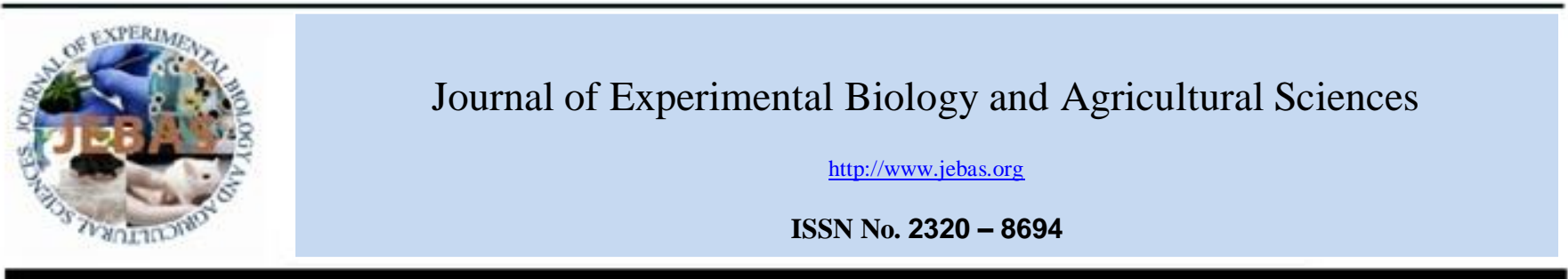

\title{
AEROBIC VERSUS ANAEROBIC GERMINATION PERFORMANCE OF SELECTED RICE (Oryza sativa L.) GENOTYPES WITH OR WITHOUT SUBMERGENCE TOLERANCE
}

\author{
Dibosh Bordoloi*, Debojit Sarma \\ ${ }^{1}$ Department of Plant Breeding and Genetics, Assam Agricultural University, Jorhat 785013, Assam
}

Received - August 29, 2018; Revision - October 21, 2018; Accepted - December 06, 2018

Available Online - December 15, 2018

DOI: http://dx.doi.org/10.18006/2018.6(6).947.958

\author{
KEYWORDS \\ Oryza sativa \\ Landrace \\ Anaerobic germination \\ Submergence tolerance \\ Genetic variability \\ Cluster analysis
}

* Corresponding author

E-mail: diboshjrt@gmail.com (Dibosh Bordoloi)

Peer review under responsibility of Journal of Experimental Biology and Agricultural Sciences.

Production and Hosting by Horizon Publisher India [HPI] (http://www.horizonpublisherindia.in/).

All rights reserved.

\begin{abstract}
Ten selected rice genotypes adapted to rainfed lowland ecosystem of Assam was evaluated for their ability to germinate and grow underwater (anoxic condition) in comparison to the aerobic condition. Anaerobic germination was allowed $10 \mathrm{~cm}$ water depth in pots partially filled with soils inside the net house, while Petri dishes lined with filter papers were used for aerobic germination. A general trend in reduction of germination and seedling traits were observed for all the genotypes. Three of the tolerant genotypes namely Badal, Swarna Sub 1 and Solpuna showed germination enhancement under anaerobic condition, the highest significant increase $(24.3 \%$ ) being registered for Badal, a cultivar adapted to semi-deep water $(42-75 \mathrm{~cm})$ situation indigenous to Assam followed by Swarna Sub 1 (11.6\%) and Solpuna (2.1\%). Both Badal and Swarna Sub 1 are tolerant to submergence at vegetative stage. Solpuna, another local cultivar adapted to the lowland ecosystem with no known submergence tolerance recorded the highest shoot length under the anoxic condition which was significantly superior to its aerobic performance. The reduction in root length was the minimum for Solpuna followed by Swarna Sub 1 and Manohar Sali. The landrace Solpuna exhibited statistically at par performance with respect to seedling length and seedling vigour index under both the environments. Seedling vigour index proved to be a reliable character for desirable improvement in rice anaerobic germination and growth. Cluster analysis grouped Solpuna separately which might be due to its unique performance under anaerobic condition. Solpuna proved its superiority over the other nine genotypes in its ability to germinate and grow under anoxic condition. The present study further indicated that AG tolerance might be independent of the submergence tolerance at the vegetative stage conferred by SUB $1 A$ gene or gene (s) with similar effects.
\end{abstract}

All the article published by Journal of Experimental Biology and Agricultural Sciences is licensed under a Creative Commons Attribution-NonCommercial 4.0 International License Based on a work at www.jebas.org.

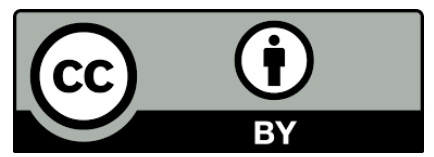




\section{Introduction}

The prevalence of flood in lowland rice ecosystems and floodprone areas of the world is a deterrent to grain production causing significant losses every year (Singh et al., 2011; Mackill et al., 2012; Miro \& Ismail, 2013; Colmer et al., 2014). In South and South-east Asia with majority rice farmers of the world, floods are the major challenges for rice production (Miro \& Ismail, 2013), which get aggravated due to uneven rainfall distribution and suffer periodic changes in frequencies and intensities in recent years caused by extreme weather events (Coumou \& Rahmstorf, 2012). However, the presence of enormous genetic diversity in rice and its growing environments ranging from upland to very deep water ecosystems has made it the most amenable crop for breeding varieties resilient to excess water conditions (Kirk et al., 2014).

Rice seed germination suffers anaerobic conditions due to uneven leveling field or early rain, and sometimes due to planned flooding as a weed control measure. Rice is the only cereal exhibiting some degree of tolerance to anaerobic conditions during germination (AG) by way of coleoptile emergence and partial growth. However, the level of tolerance is not sufficient to overcome the anoxic condition. In rainfed rice ecosystems, direct seeded rice varieties should possess anaerobic germination (AG) ability to overcome water logging during germination (Miro et al., 2017). AG tolerance is associated with faster germination and faster coleoptile elongation due to replacement of aerobic respiration by alcoholic fermentation enzymes as a source of energy (Miro et al., 2017). Under limited oxygen concentrations, rice root growth are suppressed while shoot growth increases as the oxygen concentration declines (Tsuji, 1973; Alpi \& Beevers, 1983). The length of rice coleoptiles can exceed the length of aerobic coleoptiles under anoxic conditions, but root and primary leaf fail to grow (Alpi \& Beevers, 1983). This elongation of coleoptile is supposed to enhance hollow coleoptiles thereby making contact with aerated water surface (the Snorkel effect; Kordan, 1974), and thus allows oxygen to diffuse internally to the root and endosperm (Turner et al., 1981) and supports more complete and vigorous seedling establishment.

In recent years, rice production has shifted from transplanting to direct seeding especially in areas of scarce irrigation water and high cost of labour (Pandey \& Valesco, 2002). Direct seeding can reduce labour input by as much as $90 \%$ over transplanting and crop growth duration up to 14 days (Pandey, 1995). In spite of these advantages, direct seeding method is handicapped with poor germination and seedling establishment resulting from damage due to birds, rats, snails and other biological factors; and physical damage caused by flooding, water stress, lodging at maturity and weed infestation (Angaji, 2008). Besides, poor anchorage of surface seeded rice and low initial growth rate contribute to poor crop establishment and encourage weed growth. Overcoming these constraints entails development of rice varieties capable of germinating and growing vigorously under flooded conditions. Factors like limited knowledge on the genetics of tolerance with involvement of several complex mechanisms (Seshu et al., 1988), complex genetic background and lack of an effective method for evaluation of AG (Ling et al., 2006) slow the breeding progress towards developing AG tolerance variety.

When direct sowing is followed by flooding to control weeds or it coincides with the rainy period during which the field is subjected to uncontrolled flooding, it is important to choose the varieties that possess anaerobic germination ability and exceptional seedling vigor. Popular indigenous to low land rice ecosystems and modern improved varieties with or without known submergence tolerance have not been tested rigorously for their adaptation to direct seeding under submerged condition. In view of this, a study was undertaken to evaluate the anaerobic germination of a few such rice cultivars under direct seeding in puddle condition followed by flooding with the objectives to evaluate germination and seedling traits under aerobic and anaerobic conditions and to estimate the genetic variability parameters for germination and seedling traits. Cluster analysis was performed to study the diversity pattern under both the conditions.

\section{Materials and Methods}

Two experiments were designed to investigate the germination and seedling growth of 10 selected rice genotypes under aerobic and anaerobic conditions during the summer, 2016. The anaerobic experiment was carried out inside the net house and the aerobic germination was conducted in the laboratory of the Department of Plant Breeding and Genetics, Assam Agricultural University, Jorhat.

\subsection{Experimental Materials}

The experimental materials including both indigenous and improved genotypes of rice are detailed in Table 1. The genotypes namely Lati Sail, Solpuna and Manohar Sali are adapted to rainfed lowland ecosystem whereas Badal, Jalashree, Jalkunwari and Swarna Sub 1 are known to have submergence tolerance. Badal is a land variety identified at Regional Agricultural Research Station (AAU), Karimganj. Jalashree and Jalkunwari are developed through hybridization between a semi dwarf variety Pankaj and FR 13A having SUB $1 A$ gene followed by selection for submergence tolerance. Swarna Sub 1 was developed at International Rice Research Institute, Philippines by introgression of SUB $1 A$ gene from an indica variety $F R 13 A$ in to the mega variety Swarna. Identification of the $S U B 1$ locus and the elucidation of its role in the adaptation of rice to submergence is a breakthrough in plant adaptation to anaerobiosis. Lasanthi- 
Table 1 Details of genotypes used in the study

\begin{tabular}{|cc|cccccc|}
\hline Genotypes & $\begin{array}{c}\text { Sub- } \\
\text { species }\end{array}$ & Pedigree & Origin & $\begin{array}{c}\text { Submergence } \\
\text { tolerance }\end{array}$ & Adaptation & Growing season \\
\hline Lati Sail & Indica & Land race & Assam & Unknown & Rainfed lowland & Sali (May - Jun) \\
\hline Solpuna & Indica & Land race & Assam & Unknown & Rainfed lowland & Sali (May - Jun) \\
\hline Badal & Indica & Land race & Assam & Tolerant & Rainfed lowland & Sali (May - Jun) \\
\hline Jalashree & Indica & Pankaj/FR 13A & Assam & Tolerant & Flash flood & Sali (May - Jun) \\
\hline Jalkunwari & Indica & Pankaj/FR 13A & Assam & Tolerant & Flash flood & Sali (May - Jun) \\
\hline Swarna Sub 1 & Indica & $\begin{array}{c}\text { Swarna with SUB 1A } \\
\text { from FR 13A }\end{array}$ & $\begin{array}{c}\text { IRRI, } \\
\text { Philippines }\end{array}$ & Tolerant & Flash flood & Sali (May - Jun) \\
\hline Manohar Sali & Indica & Lati Sail/Guachari & Assam & Unknown & Rainfed lowland & Sali (May - Jun) \\
\hline Ahom Sali & Indica & Land race & Assam & Unknown & Low lying areas & Boro (Nov -Dec) \\
\hline Swarna & Indica & Vasistha/Mahsuri & $\begin{array}{c}\text { Andhra } \\
\text { Pradesh }\end{array}$ & Susceptible & Shallow lowland & Sali (May - Jun) \\
\hline Ranjit & Indica & Pankaj/Mahsuri & Assam & Susceptible & Shallow lowland & Sali (May - Jun) \\
\hline
\end{tabular}

Kudahettige et al. (2007) suggested that the ability of rice seeds to germinate under complete anoxia (Alpi \& Beevers, 1983) is not likely to be explained in terms of SUB 1 gene. Solpuna, a land variety adapted to rainfed lowland ecosystem, proved its superiority over the other nine genotypes in its ability to germinate and grow under anoxic condition.

\subsection{Experimental Methods}

\subsubsection{Germination in normal aerobic condition}

Dry uniform seeds (25 seeds/Petri plate) of each genotype were first soaked in $0.1 \%$ solution of Bavistin for 24 hours and the treated seeds were lined in plastic Petri dishes with two layers of laboratory grade filter paper. The excess water from the dishes was drained out at the end of soaking. The seeds were uniformly spaced on top of the filter papers and kept in room temperature $\left(35^{\circ} \mathrm{C}\right)$ for 6 days to allow germination and seedling growth. The genotypes were replicated thrice.

\subsubsection{Germination in anaerobic condition}

For anaerobic germination, plastic pots of $30 \mathrm{~cm}$ height as well as top diameter were used. The pots were filled with finely powdered field soils of sandy loam texture up to a height of $15 \mathrm{~cm}$ after compaction and puddled by adding fresh tap water before sowing. The dry uniform seeds were soaked in $0.1 \%$ Bavistin solution for 24 hours prior to sowing. Twenty-five seeds were uniformly sown in each pot and gently pressed to a depth of $1 \mathrm{~cm}$ in to the puddled soil. Fresh tap water was slowly poured in to the pots up to a depth of $10 \mathrm{~cm}$ and kept for 6 days to allow germination and seedling growth. The water level in the pots was observed daily morning and evening to maintain a depth of $10 \pm 1 \mathrm{~cm}$. All the ten genotypes were replicated thrice.

\subsection{Sampling and observations}

All the observations were recorded on $7^{\text {th }}$ day of soaking in fungicidal solution. A random sample of five seedlings was considered for recording the various germination and growth traits. The germination of the selected rice genotypes under aerobic and anaerobic environments was evaluated for the following traits:

\subsubsection{Germination $(\%)$}

The number of seeds with coleoptile and radicle emerged was counted and expressed as percentage of the total number of seeds sown.

\subsubsection{Shoot length $(\mathrm{cm})$}

Five random seedlings were gently taken out of the submerged soil. The length of the shoot was measured from the point of attachment on the seed to the tip in $\mathrm{cm}$ and the average was worked out.

\subsubsection{Root length (cm)}

The maximum root length of the five random seedlings was measured from the point of attachment on the seed to the tip in $\mathrm{cm}$ and the average was calculated.

\subsubsection{Seedling length $(\mathrm{cm})$}

The length of each random seedling from the longest root tip to the shoot tip was measured in $\mathrm{cm}$ and the average was found out. 


\subsubsection{Seedling vigour index}

Seedling vigour index was calculated by the method given by Perry (1978) which was as follows

Seedling vigour index $=$ Seedling length $(\mathrm{cm})$ at 7 DAS $X$ Germination percentage

\subsection{Statistical analysis}

Mean data for the characters were subjected to analysis of variance following Randomized Complete Block Design for individual environments (aerobic \& anaerobic) considering replications and genotypes as fixed effects. Assuming homogeneous error variances pooled ANOVA for the characters were performed. The model for two or more environments with fixed effects (Singh \& Chaudhary, 1985) is

$$
\mathrm{Y}_{\mathrm{ijk}}=\mu+\mathrm{g}_{\mathrm{i}}+\mathrm{l}_{\mathrm{j}}+\mathrm{r}_{\mathrm{k}}+\mathrm{gl}_{\mathrm{ij}}+\mathrm{e}_{\mathrm{ijk}}
$$

Where $\mu=$ mean, $g_{i}=$ the effect of $i^{\text {th }}$ genotype, $l_{j}=$ the effect of $1^{\text {th }}$ environment, $\mathrm{r}_{\mathrm{k}}=$ the effect of $\mathrm{k}^{\text {th }}$ replication, $\mathrm{gl}_{\mathrm{ij}}=$ interaction effect of $i^{\text {th }}$ genotype with $j^{\text {th }}$ environment and $e_{i j k}=$ experimental error.

Mean squares for different sources partitioned according to Fisher's method were tested against the pooled error variances $\left(M_{e}\right)$ by applying "F-test" for significance (Fisher, 1918).

In order to test the differences among the means of the genotypes, critical differences (CD) was calculated as follows:

Analysis of variance pooled over environments

\begin{tabular}{|c|ccc|}
\hline $\begin{array}{c}\text { Source of } \\
\text { variation }\end{array}$ & $\begin{array}{c}\text { Degrees of } \\
\text { freedom }\end{array}$ & $\begin{array}{c}\text { Mean } \\
\text { squares }\end{array}$ & $\begin{array}{c}\text { Expected mean } \\
\text { squares }\end{array}$ \\
\hline Replications/E & $1(\mathrm{r}-1)$ & $M_{r / l}$ & \\
\hline Environments (E) & $(1-1)$ & $M_{l}$ & \\
\hline Genotypes (G) & $(\mathrm{g}-1)$ & $M_{g}$ & $\sigma_{e}^{2}+\mathrm{lr}_{g}^{2}$ \\
\hline $\mathrm{G} \times \mathrm{E}$ & $(\mathrm{g}-1)(1-1)$ & $M_{g l}$ & \\
\hline Pooled error & $(\mathrm{r}-1)(\mathrm{g}-1)$ & $M_{e}$ & \\
\hline \multicolumn{2}{c}{ Total } & $\mathrm{glr}-1$ & \\
\hline
\end{tabular}

$\mathrm{CD}=S E_{d} x \mathrm{t}$ for error degrees of freedom at $\mathrm{P}=0.05$ and 0.01 , where $S E_{d}=\sqrt{\frac{2 M_{e}}{r}}$

\subsubsection{Estimation of genetic parameters}

Genetic parameters were estimated as follows:

\subsubsection{Genotypic variance $\left(\sigma_{\mathrm{g}}^{2}\right)$}

This was computed according to Burton \& Devane (1953) as given below:

Genotypic variance $\left(\sigma_{g}^{2}\right):=\frac{M_{g}-M_{e}}{r l}$

\subsubsection{Phenotypic variance $\left(\sigma_{p}^{2}\right)$}

This was computed for each character by using the following formula (Falconer, 1989):

$$
\sigma_{p}^{2}=\sigma_{g}^{2}+\sigma_{e}^{2}
$$

Where, $\sigma_{e}^{2}$ is the error variance $\left(=\frac{M_{e}}{r}\right)$.

\subsubsection{Genotypic co-efficient of variation (GCV)}

This was calculated by using the formula given by Burton (1952) as follows:

$$
\operatorname{GCV}(\%)=\frac{\sigma_{g}}{\overline{\mathrm{X}}} \times 100
$$

Where, $\sigma_{g}$ is the genotypic standard deviation and $\overline{\mathrm{X}}$ is the mean for the character.

\subsubsection{Phenotypic co-efficient of variation (PCV)}

This was calculated by using the following formula given by Burton (1952):

$\operatorname{PCV}(\%)=\frac{\sigma_{p}}{\overline{\mathrm{X}}} \times 100$

Where, $\sigma_{p}$ is the phenotypic standard deviation and $\overline{\mathrm{X}}$ is the mean for the character.

\subsubsection{Heritability $\left(h_{b s}^{2}, \%\right)$}

Heritability in broad sense is the proportion of genotypic variance $\left(\sigma_{g}^{2}\right)$ to the phenotypic variance $\left(\sigma_{p}^{2}\right)$ expressed in percentage. It was calculated by using the formula by Allard (1960) as follows:

$h_{b s}^{2}(\%)=\frac{\sigma_{g}^{2}}{\sigma_{p}^{2}} \times 100$

\subsubsection{Expected genetic advance (GA)}

Expected genetic advance for each character was calculated by using the formula suggested by Hanson et al. (1956) as: 
Table 2a Anova for the traits of the 10 selected rice genotypes under aerobic environment

\begin{tabular}{|ccccccccc|}
\hline Source of variation & $d f$ & Germination & $(\%)$ & $\begin{array}{c}\text { Shoot length } \\
(\mathrm{cm})\end{array}$ & $\begin{array}{c}\text { Root length } \\
(\mathrm{cm})\end{array}$ & $\begin{array}{c}\text { Seedling } \\
\text { length (cm) }\end{array}$ & $\begin{array}{c}\text { Seedling } \\
\text { vigour Index }\end{array}$ \\
\hline Replications & 2 & 0.06 & 0.53 & 0.63 & 1.42 & 0.68 \\
\hline Genotypes & 9 & $389.90^{* *}$ & $1.27^{*}$ & $6.12^{*}$ & $10.72^{*}$ & $16.09^{* *}$ \\
\hline Error & 18 & 49.24 & 0.51 & 2.35 & 3.85 & 2.99 \\
\hline CV $(\%)$ & & 8.36 & 14.01 & 21.10 & 15.84 & 16.57 \\
\hline
\end{tabular}

Table $2 \mathrm{~b}$ Anova for the traits of the 10 selected rice genotypes under anaerobic environment

\begin{tabular}{|ccccccccc|}
\hline Source of variation & $d f$ & Germination & $(\%)$ & $\begin{array}{c}\text { Shoot length } \\
(\mathrm{cm})\end{array}$ & $\begin{array}{c}\text { Root length } \\
(\mathrm{cm})\end{array}$ & $\begin{array}{c}\text { Seedling } \\
\text { length }(\mathrm{cm})\end{array}$ & $\begin{array}{c}\text { Seedling } \\
\text { vigour Index }\end{array}$ \\
\hline Replications & 2 & 4.53 & 0.01 & 0.02 & 0.06 & 0.84 \\
\hline Genotypes & 9 & $733.91^{* *}$ & $6.96^{* *}$ & $4.14^{* *}$ & $19.79^{* *}$ & $19.26^{* *}$ \\
\hline Error & 18 & 203.92 & 0.94 & 0.40 & 2.39 & 2.26 \\
\hline CV $(\%)$ & & 18.94 & 24.09 & 28.17 & 24.66 & 30.10 \\
\hline
\end{tabular}

Table 2c Pooled anova for the traits of the 10 selected rice genotypes, rainy season 2016.

\begin{tabular}{|cccccccc|}
\hline Source of variation & $d f$ & Germination $(\%)$ & $\begin{array}{c}\text { Shoot length } \\
(\mathrm{cm})\end{array}$ & $\begin{array}{c}\text { Root length } \\
(\mathrm{cm})\end{array}$ & $\begin{array}{c}\text { Seedling length } \\
(\mathrm{cm})\end{array}$ & $\begin{array}{c}\text { Seedling vigour } \\
\text { Index }\end{array}$ \\
\hline Replications/E & 4 & 2.30 & 0.27 & 0.33 & 0.74 & 0.76 \\
\hline Environments (E) & 1 & $1105.70^{* *}$ & $17.93^{* *}$ & $378.68^{* *}$ & $561.41^{* *}$ & $443.16^{* *}$ \\
\hline Genotypes (G) & 9 & $824.80^{* *}$ & $5.24^{* *}$ & $8.22^{* *}$ & $22.22^{* *}$ & $25.31^{* *}$ \\
\hline $\mathrm{G} \times \mathrm{E}$ & 9 & $299.00^{*}$ & $3.00^{* *}$ & 2.03 & $8.29^{*}$ & $10.02^{* *}$ \\
\hline Pooled Error & 36 & 126.57 & 0.73 & 1.38 & 3.12 & 2.62 \\
\hline $\mathrm{CV}(\%)$ & & 8.15 & 10.76 & 14.24 & 10.93 & 12.13 \\
\hline
\end{tabular}

$\mathrm{GA}=\mathrm{k} \cdot \sigma_{p} \cdot h_{b s}^{2}$

Where, $\mathrm{k}=2.06$ at $5 \%$ selection intensity, $\sigma_{p}=$ Phenotypic standard deviation, $h_{b s}^{2}=$ Heritability in broad sense.

Genetic advance as percent of population mean $=\frac{G A}{\overline{\mathrm{X}}} \times 100$, where $\overline{\mathrm{X}}=$ Mean of base population.

\subsection{Cluster analysis}

The usual Euclidean distance matrix was worked out for clustering the ten genotypes using Unweighted Pair Group Method with Arithmetic mean (UPGMA) in DARwin v. 6 (Perrier \& Jacquemoud-Collet, 2006). The UPGMA tree was constructed for both aerobic and anaerobic conditions to study the clustering pattern of the ten rice genotypes.

\section{Results and Discussion}

\subsection{Analysis of variance}

The presence of significant variation among the genotypes for all the traits was evident from the environment wise analyses of variance (Table 2a $\mathbf{\&} \mathbf{2 b}$ ). The higher magnitude of experimental coefficients of variation for all the traits indicated a greater influence of oxygen stress on the various trait expressions. The pooled ANOVA over the two environments (Table 2c) revealed highly significant mean squares due to environments, indicating that anaerobic condition was quite different from the aerobic condition of germination and seedling growth of rice. Similarly, genotypic difference was also evident from highly significant mean squares for all the traits. The GE interaction component was significant for shoot length and seedling vigour index at $1 \%$ level of significance while germination (\%) and seedling length was significant at $5 \%$ level, these results suggesting differential response of the genotypes in aerobic and anaerobic conditions. 
Table 3 Mean performance of the genotypes for the traits pooled over the environments

\begin{tabular}{|c|c|c|c|c|c|}
\hline Genotype & $\begin{array}{c}\text { Germination } \\
(\%)\end{array}$ & $\begin{array}{l}\text { Shoot length } \\
(\mathrm{cm})\end{array}$ & $\begin{array}{l}\text { Root Length } \\
(\mathrm{cm})\end{array}$ & $\begin{array}{l}\text { Seedling length } \\
(\mathrm{cm})\end{array}$ & $\begin{array}{l}\text { Seedling vigour } \\
\text { index }\end{array}$ \\
\hline Lati Sail & 84.44 & 4.41 & 4.52 & 8.94 & 7.62 \\
\hline Solpuna & 82.51 & 6.16 & 5.36 & 11.53 & 9.52 \\
\hline Badal & 72.88 & 5.12 & 4.86 & 9.98 & 7.11 \\
\hline Jalashree & 57.24 & 3.04 & 3.41 & 6.46 & 4.34 \\
\hline Jalkunwari & 62.48 & 3.85 & 3.53 & 7.38 & 5.08 \\
\hline Swarna Sub 1 & 84.65 & 4.98 & 7.45 & 12.43 & 10.29 \\
\hline Manohar Sali & 91.75 & 5.18 & 4.78 & 9.95 & 9.36 \\
\hline Ahom Sali & 90.99 & 5.31 & 5.44 & 10.76 & 9.98 \\
\hline Swarna & 82.66 & 3.78 & 4.07 & 7.85 & 6.57 \\
\hline Ranjit & 87.03 & 3.91 & 4.12 & 8.03 & 7.24 \\
\hline Mean & 79.66 & 4.57 & 4.76 & 9.33 & 7.71 \\
\hline $\operatorname{SEm} \pm$ & 4.59 & 0.35 & 0.48 & 0.72 & 0.66 \\
\hline $\mathrm{CD}, 5 \%$ Gen. $(\mathrm{G})$ & 13.25 & 1.00 & 1.38 & 2.08 & 1.91 \\
\hline Env. (E) & 5.93 & 0.45 & 0.62 & 0.93 & 0.85 \\
\hline GXE & 18.74 & 1.42 & - & 2.94 & 2.70 \\
\hline
\end{tabular}

Significant mean squares for genotypes in both individual as well as pooled ANOVA could be attributed to their genetic differences for germination and growth traits as also reported by Adachi et al. (2015) for germination and seedling emergence which were attributed to the physiological responses of the rice varieties to undergo shoot elongation during submergence. Presence of genotypic differences for anaerobic germination and seedling growth traits have been also reported by Doley et al. (2018) \& Adigbo et al. (2018). The ability of rice varieties to seedling emergence during submergence has been related to their ability to use stored starch reserves through amylase activity and anaerobic respiration in rice seedlings (Manigbas et al., 2008; Kawano et al., 2009 \& Adachi et al., 2015).

\subsection{Mean performance}

Mean performances of the genotypes for individual and pooled over environments are presented in Table 3. The coefficients of variability $(\mathrm{CV})$ estimated from individual and pooled ANOVA suggested that germination and seedling traits of the genotypes were profoundly affected by anaerobiosis as evident from their higher magnitude of CVs under anoxic condition compared to performance in air.

Rice seed germination under aerobic condition ranged from $65 \%$ in Badal to $100 \%$ in Manohar Sali while anaerobic germination was the lowest in Jalashree (44.48\%) and the highest in Swarna
Sub $1(89.31 \%)$. The anaerobic germination was more than 75 percent for the genotypes namely Swarna Sub 1, Ahom Sali, Manohar Sali, Solpuna, Lati Sail, Badal, Ranjit and Swarna indicating their tolerance to anaerobiosis (Figure 1a). Jalashree and Jalkunwari exhibiting less than 50 percent germination under anaerobic condition could be considered as susceptible genotypes considering the classification of Manigbas et al. (2008). According to Miro et al. (2017), coleoptile elongation and percent germination are the two most important traits associated with AG tolerance. Three of the tolerant genotypes namely Badal, Swarna Sub 1 and Solpuna showed germination enhancement under anaerobic condition and the highest significant increase (24.3\%) was registered for Badal, a cultivar adapted to semi deep water $(42-75 \mathrm{~cm})$ situation indigenous to Assam.

The maximum reduction in shoot length (Figure 1b) under anaerobic condition was noted for Jalashree followed by Ranjit and Jalkunwari, whereas the decrease was the lowest in Badal followed by Swarna Sub 1 and Lati Sail. Solpuna recorded the highest shoot length under anoxic condition which was significantly superior over its aerobic performance. Adigbo et al. (2010) assumed that the already germinating seedling could continue the process of germination in saturated soil. This was further corroborated by the shoot elongation of germinating seeds during submergence attributed to genetic factor (Adachi et al., 2015). 
The root length (Figure 1c) was significantly reduced for all the genotypes under anaerobic condition. However, the reduction was the minimum for Solpuna followed by Swarna Sub 1 and Manohar Sali. Swarna Sub 1 registered the highest root length in both the environments and was followed by Ahom Sali in aerobic and Solpuna in anaerobic condition. With limiting $\mathrm{O}_{2}$, rice root growth are suppressed while shoot growth increases as the concentration declines (Tsuji, 1973; Alpi \& Beevers, 1983).

The landrace Solpuna exhibited statistically at par performance with respect to seedling length (Figure 1d) and seedling vigour index (Figure 1e) under both the environments. All other genotypes showed significant reduction in seedling length and seedling vigour index under anaerobic condition as compared to aerobic environment. Considerable variation among rice genotypes for coleoptile extension during anoxia was observed by Setter et al. (1994). Genotypic differences in anaerobic germination, shoot and root growth were also reported by Manigbas et al. (2008). In submerged fields, coleoptile elongation ability under anoxic condition might influence crop establishment by enabling the seedlings to come contact with the air and thus to gain access to $\mathrm{O}_{2}$ (Huang et al., 2003).

Rice can tolerate complete submergence due to a number of adaptive mechanisms, which include an ability to elongate submerged shoot organs at faster than normal rates and to develop aerenchyma for efficient internal transport of oxygen from the re-emerged elongated shoot to submerged parts. However, rice seeds can germinate anaerobically by means of coleoptile elongation. Although there is still much to learn about the biochemical and molecular basis of anaerobic rice germination, the ability of rice to maintain an active fermentative metabolism (by fuelling the glycolytic pathway with readily fermentable carbohydrates) is certainly crucial

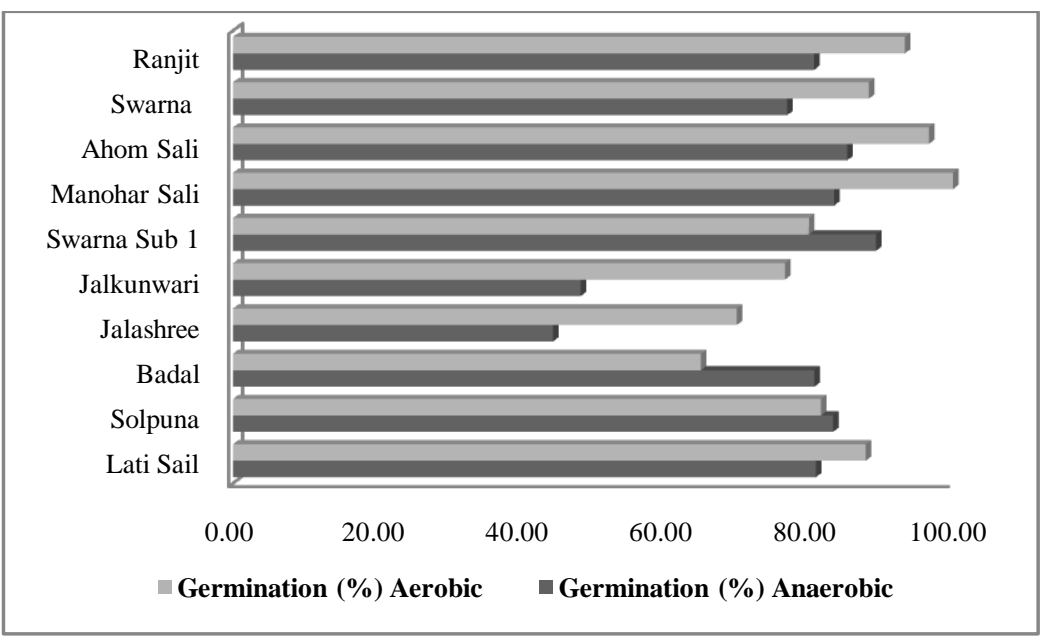

Figure 1a: Aerobic and anaerobic germination of ten rice genotypes.

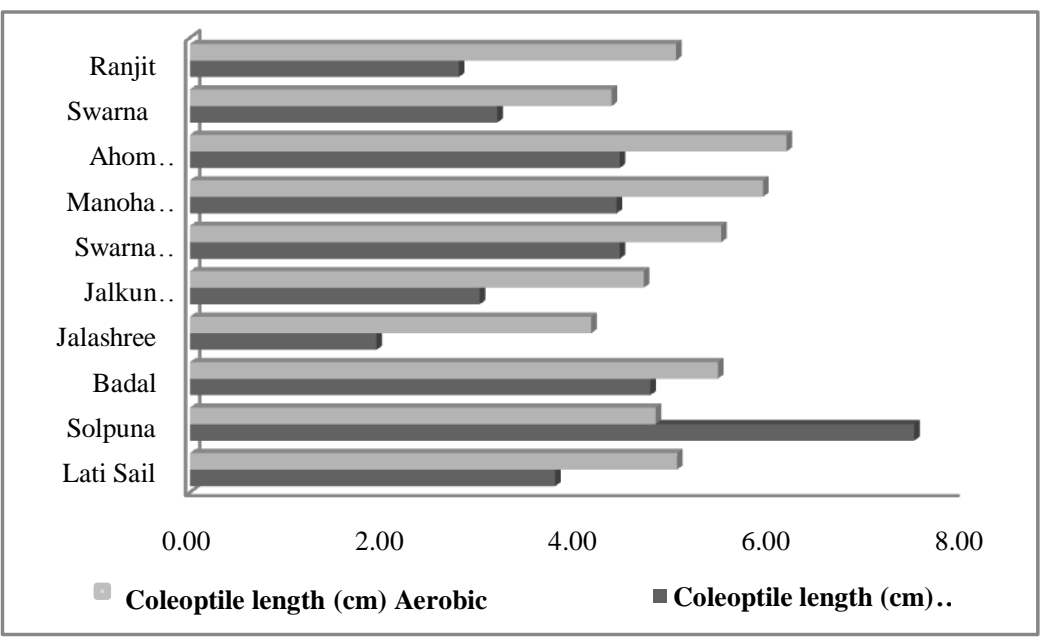

Figure 1b: Aerobic and anaerobic coleoptile growth of ten rice genotypes.

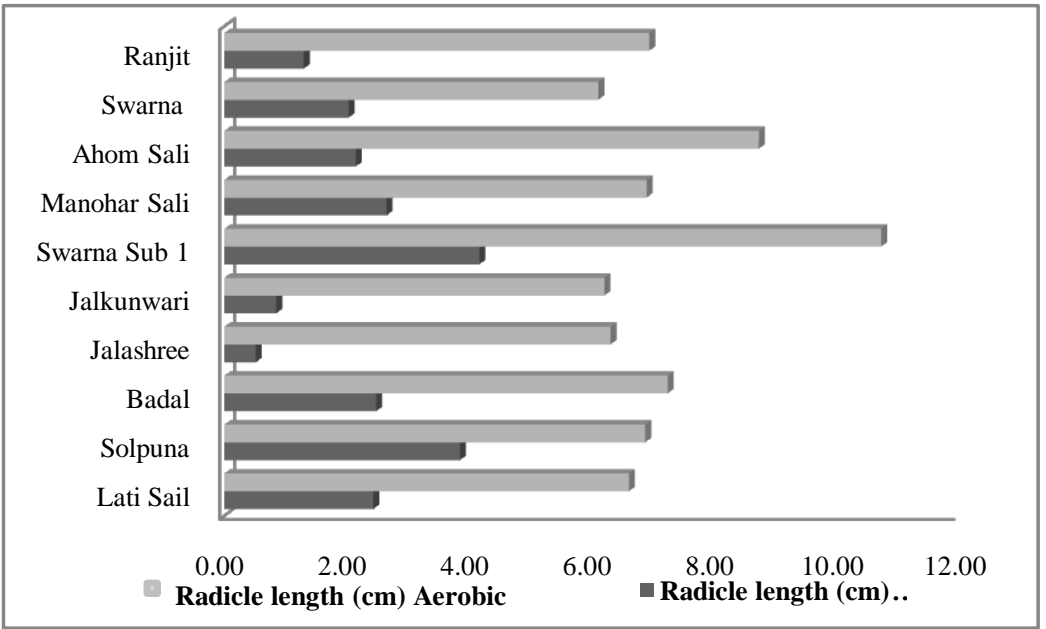

Figure 1c: Aerobic and anaerobic radicle growth of ten rice genotypes. 
(Magneschi \& Perata, 2009; Magneschi et al., 2009). The variety Solpuna identified in present study could be further studied for its specific adaptive mechanism of anaerobiosis.

\subsection{Genetic variability}

The success of any crop improvement programme depends on the magnitude of genetic variability for the different traits and the extent to which the desirable trait is heritable. In order to understand the extent of variability, caused by genetic factors, the phenotypic and genotypic variances, phenotypic and genotypic coefficients of variations, broad sense heritability and genetic advances were worked out. Range, mean ( $\pm \mathrm{SE}$ ), GCV, PCV, $h_{b s}^{2}$ and GA as $\%$ of mean are presented in Table 4.

A perusal of Table 4 revealed the widest range of variability for root length followed by seedling vigour index and shoot length. Germination recorded the lowest range of variability as also evident from the lowest estimates of GCV and PCV for this character. However, these estimates were moderate in strength. The highest GCV and PCV were obtained for seedling vigour index followed by root length, seedling length and shoot length. The estimates were high (>20\%) for the first two characters and moderate (10$20 \%$ ) for the latter two characters. The heritability and genetic advance were also high for seedling vigour index. The heritability was moderate $(60-80 \%)$ for the remaining characters. The genetic advance

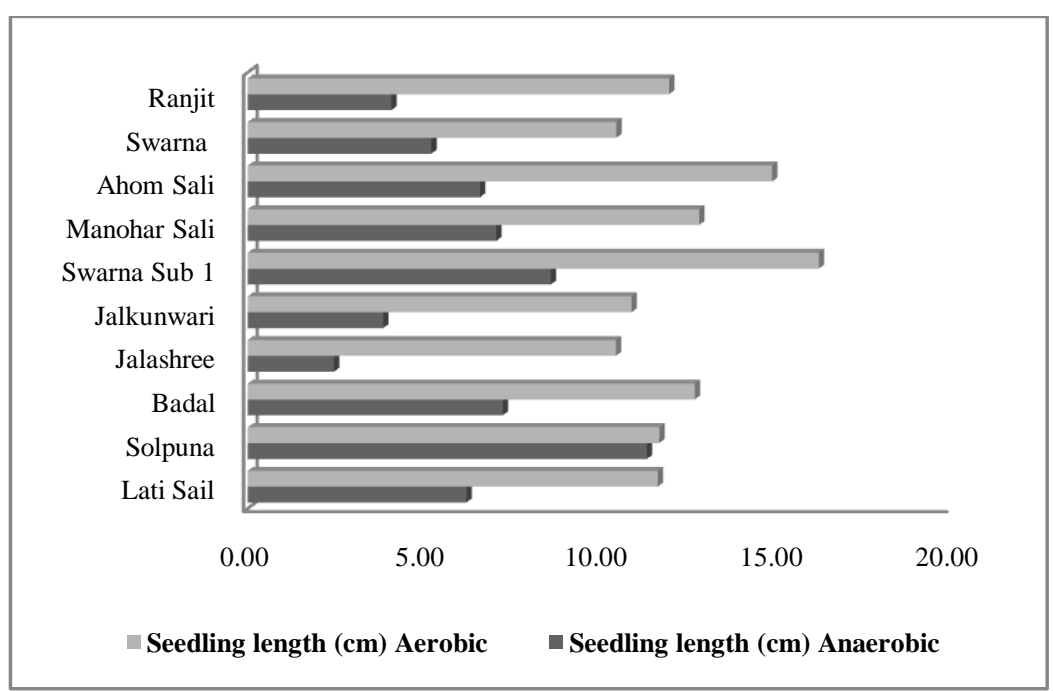

Figure 1d: Aerobic and anaerobic seedling growth of ten rice genotypes.

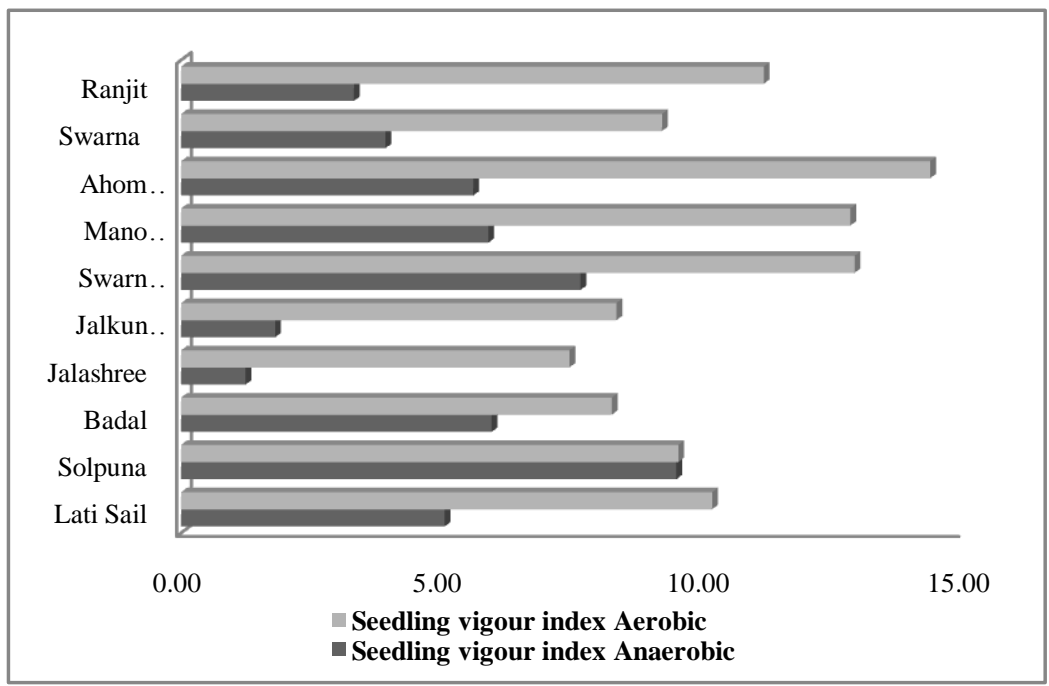

Figure 1e: Aerobic and anaerobic seedling vigour index of the ten rice genotypes.

Table 4 Genetic variability for the traits in 10 selected rice genotypes estimated from pooled ANOVA

\begin{tabular}{|lcccccc|}
\hline Character & Range & Mean \pm SEm & GCV (\%) & PCV (\%) & $\begin{array}{c}h^{2} \text { bs }(\%) \\
\text { GA, of } \\
\text { mean }\end{array}$ \\
\hline Germination (\%) & $62.48-91.74$ & $79.66 \pm 6.50$ & 13.54 & 15.81 & 73.39 & 23.9 \\
\hline Shoot length (cm) & $3.04-6.16$ & $4.57 \pm 0.49$ & 18.97 & 21.8 & 75.65 & 33.98 \\
\hline Root length (cm) & $3.41-7.45$ & $4.76 \pm 0.68$ & 22.46 & 26.59 & 71.31 & 39.07 \\
\hline Seedling length (cm) & $6.46-12.43$ & $9.33 \pm 1.02$ & 19.13 & 22.03 & 75.38 & 34.21 \\
\hline Seedling vigour index & $4.34-10.29$ & $7.71 \pm 0.93$ & 25.22 & 27.98 & 81.22 & 46.82 \\
\hline
\end{tabular}

Journal of Experimental Biology and Agricultural Sciences http://www.jebas.org 
Table 5a Genotypic (above diagonal) and phenotypic (below diagonal) correlation coefficients among the characters under aerobic condition

\begin{tabular}{|ccc|ccc|}
\hline Character & $\begin{array}{c}\text { Germination } \\
(\%)\end{array}$ & $\begin{array}{c}\text { Seedling height } \\
(\mathrm{cm})\end{array}$ & $\begin{array}{c}\text { Root length } \\
(\mathrm{cm})\end{array}$ & $\begin{array}{c}\text { Seedling length } \\
(\mathrm{cm})\end{array}$ & $\begin{array}{c}\text { Seedling vigour } \\
\text { index }\end{array}$ \\
\hline Germination $(\%)$ & & $0.70^{* *}$ & 0.14 & 0.34 & $0.84^{* *}$ \\
\hline Seedling height $(\mathrm{cm})$ & 0.26 & & $0.69^{* * *}$ & $0.95^{* *}$ \\
\hline Root length $(\mathrm{cm})$ & 0.01 & $0.53^{* *}$ & & $0.97^{* *}$ \\
\hline Seedling length $(\mathrm{cm})$ & 0.10 & $0.76^{* *}$ & $0.95^{* *}$ & $0.79^{* *}$ \\
\hline Seedling vigour index & $0.65^{* *}$ & $0.73^{* *}$ & $0.73^{* *}$ & $0.82^{* *}$ \\
\hline
\end{tabular}

*, ** Significant at $5 \%$ and $1 \%$ level, respectively

Table 5b Genotypic (above diagonal) and phenotypic (below diagonal) correlation coefficients among the characters under anaerobic condition

\begin{tabular}{|cccccc|}
\hline Character & $\begin{array}{c}\text { Germination } \\
(\%)\end{array}$ & $\begin{array}{c}\text { Seedling height } \\
(\mathrm{cm})\end{array}$ & $\begin{array}{c}\text { Root length } \\
(\mathrm{cm})\end{array}$ & $\begin{array}{c}\text { Seedling length } \\
(\mathrm{cm})\end{array}$ & $\begin{array}{c}\text { Seedling vigour } \\
\text { index }\end{array}$ \\
\hline Germination $(\%)$ & & $0.73^{* *}$ & $0.97^{* *}$ & $0.88^{* *}$ & $0.87^{* *}$ \\
\hline Seedling height $(\mathrm{cm})$ & $0.45^{*}$ & & $0.81^{* *}$ & $0.96^{* *}$ & $0.94^{* *}$ \\
\hline Root length $(\mathrm{cm})$ & $0.58 * *$ & $0.82 * *$ & & $0.94^{* *}$ & $0.98^{* *}$ \\
\hline Seedling length $(\mathrm{cm})$ & $0.53 * *$ & $0.97 * *$ & $0.94 * *$ & $0.96^{* *}$ \\
\hline Seedling vigour index & $0.72 * *$ & $0.91 * *$ & $0.92 * *$ & 0.01 \\
\hline$* * *$ Significant at $5 \%$ and $1 \%$ lel & & &
\end{tabular}

*,** Significant at $5 \%$ and $1 \%$ level, respectively

was also moderate $(30-50 \%)$ for the remaining characters except germination percentage. The high estimates of genetic variability, heritability and genetic advance for seedling vigour index was implicative of its worth as an important criterion for simple selection. The high values of GCV and PCV were obtained for seedling vigour index and root length indicating that variation for these two characters contributed markedly to the total variability. Further, narrow range of difference between PCV and GCV indicated that any selection pressure operated on these characters may help to realize improvement at early generation.

Johnson et al. (1955) suggested that heritability and genetic advance when calculated together would prove more useful in predicting the resultant effect of selection on phenotypic expression, without genetic advance the estimates of heritability will not be of practical value and emphasized the concurrent use of genetic advance along with heritability. In present study seedling vigour index could be a reliable character for desirable improvement in rice anaerobic germination and growth. Seedling vigour is an indicator of potential seed germination, seedling growth and tolerance to adverse climatic factors (Mahender et al., 2015), and it contributes to improved speed, uniformity and percentage of germination leading to high yield potential under direct seeded conditions (Foolad et al., 2007).

\subsection{Character interrelationship}

The estimates of phenotypic and genotypic correlation coefficients among the traits under aerobic condition (Table 5a \& 5b) suggested that germination had no correlation with the seedling traits except seedling vigour index at phenotypic level. At genotypic level, seedling height and seedling vigour index were positively correlated with germination. The seedling vigour index was positively correlated with all other traits at both genotypic and phenotypic level. The correlation coefficients among seedling height, root length and seedling length were also positive at both the levels.

Under anaerobic condition, all the traits were positively correlated among themselves at both the levels. Similar results on Pearson's correlation coefficients were also reported by Doley et al. (2018) among anaerobic germination, seedling vigour index and coleoptile length; and between seedling length, seedling vigour index and coleoptile length. Seedling vigour index combining both seedling length (shoot plus root) and germination was found to be the most important parameter for assessing anaerobic germination performance and growth in rice. El-Hendawy et al. (2014) emphasized the role of adaptive traits associated with submergence tolerance at the initial growth stage to enhance seedling establishment of direct-seeded rice. Germination and early seedling growth have been identified as the two major traits associated with rapid shoot elongation during submergence (Cui et al. 2002) which depend on genetic architecture and are affected by the state of seedling growth before submergence (El-Hendawy et al., 2014). According to El-Hendawy et al. (2014), a rapid elongation of coleoptile under submerged conditions can be targeted in tolerant genotypes to escape or avoid complete submergence during the initial growth stage. 


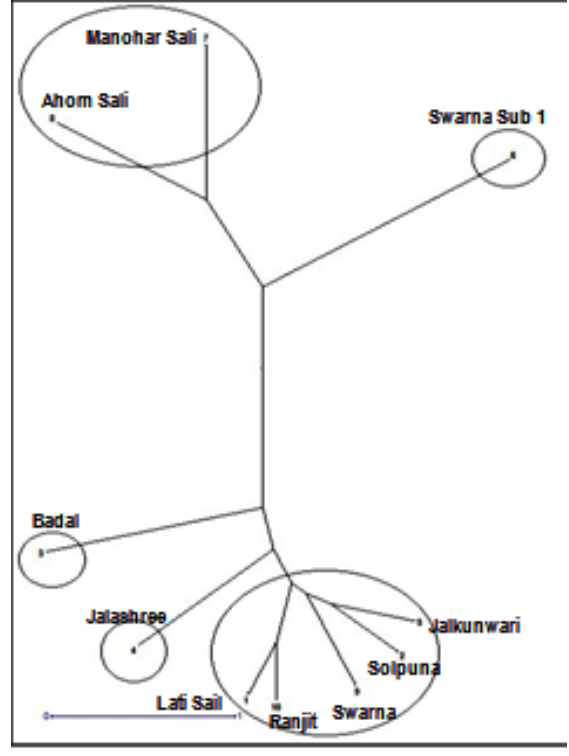

Figure 2a: UPGMA based tree of the ten rice genotypes using usual Euclidean distance aerobic condition

\subsection{Cluster analysis}

The clustering pattern of the aerobically grown genotypes distorted from the anaerobic pattern with the exception that Swarna Sub 1 was grouped separately in both the conditions (Figure 2a \& 2b). The other genotypes did not show any specific pattern under aerobic condition. Under anaerobic condition, the ten rice genotypes were grouped into five clusters. All the genotypes adapted to semi deep water situation viz. Manohar Sali, Badal, Ahom Sali and Lati Sail belonged to the same cluster while the modern high yielding varieties Swarna and Ranjit adapted to shallow lowland ecosystem were clustered together. The exception was Solpuna being grouped separately which might be due to its unique performance under anaerobic condition. The submergence tolerant Jalashree and Jalkunwari originating from the cross Pankaj/FR 13A were grouped together while Swarna Sub 1 with the SUB $1 A$ gene from FR 13A was grouped alone. Such differential expression of AG potential among submergence tolerant genotypes was also suggested by Doley et al. (2018). The studies of Vu et al. (2010), Sarkar \& Bhattacharjee (2011) and ElHendawy et al. (2014) also established that the presence of SublA does not always restrict shoot elongation under submergence at the early seedling stage of rice. Further, the expression of the specific adaptive traits of a genotype also depends on the growing environment to which it is exposed.

\section{Conclusion}

Rice seeds can germinate in the complete absence of oxygen. Under anoxia, the rice coleoptile elongates, reaching a length greater than that of the aerobic one. The present study provided

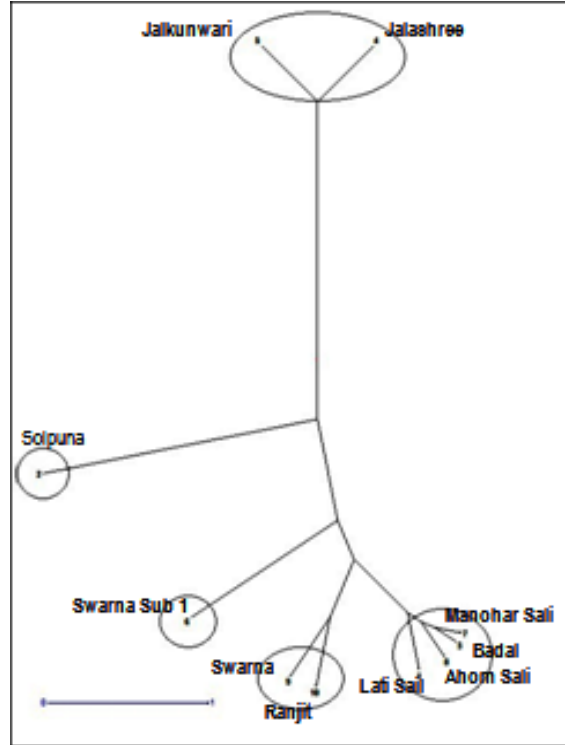

Figure 2b: UPGMA based tree of the tem rice genotypes using usual Euclidean distance under anaerobic condition

evidence for the presence of genetic differences in anoxic germination and coleoptile elongation. Solpuna has been a good example of rice varieties having significant superiority in its ability to germinate and grow anaerobically. However, this variety is tall traditional type and easily lodges. As direct-seeded rice (DSR) cultivation is increasingly being practiced among farmers in both rainfed and irrigated ecosystems because of labour scarcity, water shortage, and high production cost, genetic improvement of Solpuna for a non-lodging semi dwarf plant type or transferring its anoxic germination traits to other improved semi dwarf background have been suggested to encourage large scale adoption of DSR practices. Because poor crop establishment or a total loss of the crop stand due to improperly leveled fields, heavy rainfall and poor drainage have led to the accumulation of water of varying depths immediately after sowing or during germination. Therefore, developing high yielding varieties that can withstand flooding during germination and early growth is essential for sustainability of practicing direct seeding for rice crop establishment.

Further, NE India is endowed with enormous rice genetic resources which have not yet been investigated for special characteristics such as the one undertaken in the present study. Thus, understanding the underlying mechanisms of anaerobic germination would be better insighted in a wide range of germplasm base using physiological, biochemical and molecular tools.

\section{Conflict of Interest}

There is no conflict of Interest. 


\section{References}

Adachi Y, Sugiyama M, Sakagami J, Fukuda A, Ohe M, Watanabe H (2015) Seed Germination and Coleoptile Growth of New Rice Lines Adapted to Hypoxic Conditions. Plant Production Science 18: 471-475.

Adigbo SO, Ojerinde AO, Ajayi O, Nwilene FE (2010) Effect of Sowing Methods on Performance of Upland Rice in Lowland Rice-Upland Rice-Vegetable Sequence in Inland Valley. Journal of Agricultural Science and Technology (Serial 28) 4: 1-10.

Adigbo SO, Osadebay PJ , Iseghohi I, Alarima CI, Agbenin NO, Odedina JN , Fabunmi TO (2018) Screening and evaluation of upland rice (Oryza sativa L.) varieties in inundated soil. Agricultura Tropica Et Subtropica 51: 63-69. DOI: 10.1515/ats-2018-0007

Allard RW (1960) Principles of plant breeding, John Wiley \& Sons Inc, New York, p.85.

Alpi A, Beevers H (1983) Effects of $\mathrm{O}_{2}$ concentration on rice seedlings. Plant Physiology 71: 30-34.

Angaji SA (2008) Mapping QTLs for submergence tolerance during germination in rice. African Journal of Biotechnology 7: 2551-2558.

Burton GV (1952) Quantitative inheritance in pearl millet. Agronomy Journal 50: 503.

Burton GW, Devane EM (1953) Estimating heritability in tall fescus (Festuca arundiaceae) from replicated clonal material. Agronomy journal 45: 478-485.

Colmer TD, Armstrong W, Greenway H, Ismail AM, Kirk GJD, Atwell BJ (2014) Physiological mechanisms of flooding tolerance in rice: transient complete submergence and prolonged standing water. In: Luttge U, Beyschlag W, Cushman J (Eds.), Progress in botany 75 Berlin, Heidelberg: Springer, Pp. 255-307. DOI: 10.1007/978-3-642-38797-5_9

Coumou D, Rahmstorf S (2012) A decade of weather extremes. Nature Climate Change 2: 491-496.

Cui KH, Peng SB, Xing YZ, Xu CG, Yu SB, Zhang Q (2002) Molecular dissection of seedling-vigor and associated physiological traits in rice. Theoretical and Applied Genetics 105: $745-753$.

Doley D, Barua M, Sarma D, Barua PK (2018) Screening and enhancement of anaerobic germination of rice genotypes by presowing seed treatments. Current Science 115: 1185-1190 Doi: $10.18520 / \mathrm{cs} / \mathrm{v} 115 / 16 / 1185-1190$
El-Hendawy S, Al-Suhaibani N, Schmidhalter U, Sakagami JI (2014) Adaptive traits associated with tolerance to flash flooding during emergence and early seedling growth stages in rice. Plant Omics Journal 7:474-489.

Falconer DS (1989) Introduction to Quantitative Genetics. 3rd Edition. ELBS / Longman.

Fisher RA (1918) The correlation between relatives on the supposition of Mendelian inheritance. Transactions Royal Society Edinburgh 52: 399-433.

Foolad MR, Subbiah P, Zhang L (2007) Common QTL affect the rate of tomato seed germination under different stress and nonstress conditions. International Journal of Plant Genomics 2007:1-10. doi:10.1155/2007/ 97386

Hanson CH, Robinson HF, Comstock RE (1956) Biometrical Studies of Yield in Segregating Populations of Korean Lespedeza. Agronomy Journal 48: 268-272. DOI: 10.2134/agronj1956.00021962004800060008x

Huang SB, Greenway H, Colmer TD (2003) Anoxia tolerance in rice seedlings: exogenous glucose improves growth of an anoxia'intolerant', but not of a 'tolerant' genotype. Journal of Experimental Botany 54: 2363-2373.

Johnson HW, Robinson HF, Comstock RE (1955) Estimates of genetic and environmental variability in soybean. Agronomy Journal 47: 314-318.

Kawano N, Ito O, Sakagami J. (2009) Morphological and physiological responses of rice seedlings to complete submergence (flash flooding). Annals of Botany 103: 161-169.

Kirk GJD, Greenway H, Atwell BJ, Ismail AM, Colmer TD (2014) Adaptation of rice to flooded soils. In: Luttge U, Beyschlag W, Cushman J (Eds.), Progress in botany Berlin, Heidelberg: Springer, 75 Pp. 215-253. DOI: 10.1007/978-3-64238797-5_8.

Kordan HA (1974) Patterns of shoot and root growth in rice seedlings germinating under water. Journal of Applied Ecology 11: 685-690.

Lasanthi-Kudahettige R, Magneschi L, Loreti E, Gonzali S, Licausi F, Novi G (2007) Transcript profiling of the anoxic rice coleoptile. Plant Physiology 144: 218-231.

Ling J, Liu S, Hou M, Tang J, Chen L, Zhai H, Wan J (2006) Analysis of QTLs for seed low temperature germinability and anoxia germinability in rice (Oryza sativa L.). Field Crops Research 98: 68-75. 
Mackill DJ, Ismail AM, Singh US, Labios RV, Paris TR (2012) Development and rapid adoption of submergence-tolerant (Sub1) rice varieties. Advances Agronomy 115: 303-356. DOI: 10.1016/B978-0-12-394276-0.00006-8.

Magneschi L, Perata P (2009) Rice germination and seedling growth in the absence of oxygen. Annals of Botany 103: 181-196.

Magneschi L, Kudahettige RL, Alpi A, Perata P (2009) Comparative analysis of anoxic coleoptile elongation in rice varieties: relationship between coleoptile length and carbohydrate levels, fermentative metabolism and anaerobic gene expression Plant Biology 11: 561-573 Doi:10.1111/j.14388677.2008.00150.x

Mahender A, Anandan A, Pradhan SK (2015) Early seedling vigour, an imperative trait for direct-seeded rice: an overview on physio-morphological parameters and molecular markers. Planta 241:1027-1050. DOI: 10.1007/s00425-015-2273-9.

Manigbas NL, Solis RO, Barroga WV, Noriel AJ, Arocena EC, Padolina TF, Cruz RT (2008) Developments of screening methods for anaerobic germination and seedling vigour in direct wet-seeded rice culture. Philippines Journal of Crop Science 33: 34-44.

Miro B, Ismail AM (2013) Tolerance of anaerobic conditions caused by flooding during germination and early growth in rice (Oryza sativa L.). Frontiers in Plant Science 4: 269. DOI: $10.3389 /$ fpls.2013.00269.

Miro B, Longkumar T, Entila FD, Kohli A, Ismail AM (2017) Rice Seed Germination Underwater: Morpho-Physiological Responses and the Bases of Differential Expression of Alcoholic Fermentation Enzymes. Frontiers in Plant Science 8: 1857. Doi: $10.3389 /$ fpls.2017.01857.

Pandey S, Velasco L (2002) Economics of direct seeding in Asia: patterns of adoption and research priorities. In: Pandey S, Mortimer M, Wade L, Lopez K, Hardy B (Eds.) Direct seeding: research strategies and opportunities, pp 3-8.

Pandey S (1995) Socio-economic research issues on wet seeding.
In: Constraints, Opportunities, and Innovations for Wet Seeded Rice, IRRI: 73-79.

Perrier X, Jacquemoud-Collet JP (2006) DARwin software. Available on http://darwin.cirad.fr/ access on $25^{\text {th }}$ April, 2018.

Perry DA (1978) Handbook of vigour test methods. International Seed testing Association, Zurich.

Sarkar RK, Bhattacharjee B (2011) Rice genotypes with SUB1 QTL differ in submergence tolerance, elongation ability during submergence and re-generation growth at re-emergence. Rice 5: 1-11.

Seshu DV, Krishnasamy V, Siddique SB (1988) Rice seed health. Los Baños, Philippines: International Rice Research Institute; Seed vigour in rice, pp. 315-329.

Setter TL, Ella ES, Valdez AP (1994) Relationship between coleoptile elongation and alcoholic fermentation in rice exposed to anoxia. 2. Cultivar differences. Annals of Botany 74: 273-279.

Singh RK, Chaudhary, BD (1985) Biometrical methods in quantitative genetic analysis. Revised Edition. Kalyani Publishers, New Delhi.

Singh S, Mackill DJ, Ismail AM (2011) Tolerance of longer-term partial stagnant flooding is independent of the SUB1 locus in rice. Field Crops Research 121: 311-323. DOI: 10.1016/j.fcr.2010.12.021.

Tsuji H (1973) Growth and metabolism in plants under anaerobic conditions. Environment Control in Biology 11: 79-84.

Turner FT, Chen CC, McCauley GN (1981) Morphological development of rice seedlings in water at controlled oxygen levels. Agronomy Journal 73: 566-570.

Vu HTT, Manangkil OE, Mori N, Yoshida S, Nakamura C (2010) Post-germination seedling vigor under submergence and submergence-induced SUB1A gene expression in indica and japonica rice (Oryza sativa L.). Australian Journal of Crop Science 4: 264-272. 